\title{
Genetic Relationships among Bacterial Endosymbionts of Paramecium aurelia: Deoxyribonucleotide Sequence Relationships among Members of Caedobacter
}

\author{
By ROBERT L. QUACKENBUSH* \\ Department of Biology, Indiana University, Bloomington, Indiana 47401, U.S.A.
}

(Received 25 April 1978)

\begin{abstract}
Genetic relationships among bacterial endosymbionts of Paramecium assigned to the genus Caedobacter Preer et al. 1974 were determined using DNA-DNA hybridization techniques. It was shown that mu, nu and pi endosymbionts are closely related to each other, but not to any of the strains of kappa endosymbionts tested, and that kappa consists of at least three distinct and genetically diverse groups. Therefore, it is proposed that Caedobacter be split into two genera, Caedobacter and Pseudocaedobacter, depending upon the ability or lack of ability, respectively, to produce cells containing $\mathrm{R}$ bodies. Strains were screened for covalently closed, circular DNA by ethidium bromide/ $\mathrm{CsCl}$ centrifugation, but only pi and hump-killer kappa particles were found to contain this form of DNA.
\end{abstract}

\section{INTRODUCTION}

Various strains of the Paramecium aurelia species complex (Sonneborn, 1975) are infected by bacterial endosymbionts. Several types of these endosymbionts are notable because of their killing activity when exposed to sensitive strains of paramecia. Of the nine types of bacterial endosymbionts (J. R. Preer et al., 1974) known to occur in the P. aurelia species complex, five have been assigned to a single genus, Caedobacter, containing four species:

1. C. taeniospiralis, commonly known as kappa and pi particles. Kappa particles are toxic to sensitive strains of paramecia. Each strain of kappa produces specific pre-lethal effects in affected paramecia. These are: (i) development of an aboral blister (hump-killing); (ii) immobilization (paralysis); (iii) development of an increasingly large vacuole or simple swelling (vacuolization); or (iv) reversal of the direction of rotation while swimming (spinkilling). Only certain individuals within a population of kappa particles, known as bright particles, can cause killing activity against sensitive paramecia (Smith, 1961; Mueller, 1963). These bright particles contain a large cylindrical refractile inclusion ( $\mathrm{R}$ body), about $0.5 \mu \mathrm{m}$ long and $0.5 \mu \mathrm{m}$ diam., which is a tightly coiled proteinaceous ribbon about $10 \mu \mathrm{m}$ long and $13 \mathrm{~nm}$ thick (Anderson et al., 1964). Only kappa particles can produce $\mathrm{R}$ bodies. Pi particles were originally believed to be non-killer mutants of kappa which had lost the ability to produce $\mathrm{R}$ bodies.

2. C. conjugatus, commonly known as mu particles. Mu-bearing paramecia are referred to as mate-killers because cell-to-cell contact between killer and sensitive paramecia is required for killing to occur.

3. C. falsus, commonly known as nu particles. Nu particles cause no known killing activity against their host paramecia.

4. C. minutus, commonly known as gamma particles. Gamma particles cause a strong killing activity (vacuolization) against sensitive paramecia.

* Present address: Department of Microbiology and Immunology, School of Medicine, University of Washington, Seattle, Washington 98195, U.S.A. 
Recent investigations (Dilts, 1977; Quackenbush, 1977a, b) have suggested that Caedobacter may consist of genetically diverse groups of bacteria. This communication describes attempts to determine to what extent representative strains of the major groups within Caedobacter are genetically related on the basis of DNA homologies. Special attention is given to the genetic relationships of five of the six classes of kappa particles described by Preer et al. (1972).

The genetic determinants of the distinguishing trait ( $\mathrm{R}$ body production) of kappa particles are most probably carried on extrachromosomal elements within them (Preer et al., 1971; Dilts, 1976, 1977). Since some of these extrachromosomal elements are known to be covalently closed, circular DNA (Dilts, 1976, 1977; Quackenbush, 1977 b), an attempt was made to determine whether this form of DNA occurs generally among the members of Caedobacter.

\section{METHODS}

Organisms. The paramecia used (Table 1) included representatives of five of the six classes of kappa described by Preer et al. (1972). All strains were obtained from the culture collection of J. R. Preer, Jr (Department of Biology, Indiana University, Bloomington, Indiana, U.S.A.) except for those bearing $138 \mathrm{mu}$ and 139 pi (Table 1) which were kindly provided by A. T. Soldo (Research Laboratories, Veterans Administration Hospital, Miami, Florida, U.S.A.). Escherichia coli B was obtained from the Microbiology Culture Collection, Indiana University.

Media and grow'th conditions. Paramecia containing $138 \mathrm{mu}, 139 \mathrm{pi}$ and $1010 \mathrm{nu}$ were grown axenically as described by Soldo et al. (1966) at $27^{\circ} \mathrm{C}$. Those containing 51 kappa and $540 \mathrm{mu}$ were grown using Chlamydomonas reinhardii as the food organism at room temperature $\left(20\right.$ to $\left.25^{\circ} \mathrm{C}\right)$ as described by L. B. Preer $e t$ al. (1974) and Quackenbush (1977a). All other strains were grown using E. coli B as the food organism in Cerophyl medium (Sonneborn, 1970); those containing class 51 kappas were grown at room temperature, those containing class 7 kappas, 511 kappa, 1038 kappa or 551 mu were grown at $27^{\circ} \mathrm{C}$, and that containing $51 \mathrm{~m} 1$ kappa was grown at $30^{\circ} \mathrm{C}$. Escherichia coli B was grown in Beef Heart Infusion (Difco) on a rotary shaker at $37^{\circ} \mathrm{C}$.

Purification of endosymbionts. Class 7 kappas and 1038 kappa were purified from material released on lysis of host paramecia by elution from columns of ground filter paper (Whatman Ashless Tablets) (Preer \& Preer, 1967). Other endosymbionts were purified using columns of epichlorhydrin triethanolamine cellulose (ECTEOLA; ICN Pharmaceuticals, Irvine, California, U.S.A.) as described by J. R. Preer, Jr, in a review by Sonneborn (1970). Class 51 kappas, 511 kappa and $51 \mathrm{~m} 1$ kappa were collected in the ECTEOLA wash, but an additional wash with a high salt buffer $\left(0.5 \mathrm{M}-\mathrm{NaCl}, 5 \mathrm{mM}-\mathrm{Na}_{2} \mathrm{HPO}_{4}, \mathrm{pH} 8.0\right)$ was needed to elute $\mathrm{mu}, \mathrm{nu}$ and pi particles. Microscopic examination of purified endosymbiont preparations revealed less than $1 \%$ contamination by other bacteria.

Preparation of DNA. Pellets of purified endosymbionts were suspended in saline EDTA (0.15 $\mathrm{M}-\mathrm{NaCl}$,

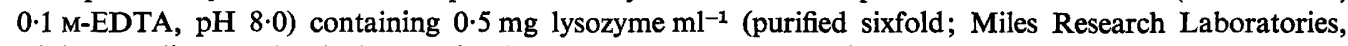
Elkhart, Indiana, U.S.A.). An equal volume of saline EDTA containing $2 \%(w / v)$ Sarkosyl (ICN Pharmaceuticals) and $50 \mu \mathrm{g}$ Proteinase $\mathrm{K} \mathrm{m}^{-1}$ (Beckman Instruments) was then added. Lysis was allowed to proceed at $60^{\circ} \mathrm{C}$ for $30 \mathrm{~min}$. DNA was purified and screened for the presence of circular DNA by ethidium bromide/ $\mathrm{CsCl}$ buoyant density centrifugation (Dilts, 1976). Ethidium bromide was removed from the DNA by dialysis against Dowex $\mathrm{Na}^{+}$resin (Thompson et al., 1974) and $\mathrm{CsCl}$ was removed by exhaustive dialysis against $5 \mathrm{~mm}-\mathrm{NaCl}$.

Purified bacteriophage DNA from 562 kappa was kindly donated by Dr Judith A. Dilts (William Jewell College, Liberty, Missouri, U.S.A.).

Radioactive labelling of DNA, fragmentation and DNA-DNA hybridization were performed as previously described (Quackenbush, 1977a). Percentage hybridization was corrected for self-reaction of radioactively labelled DNA (tracer). Homology between heterologous DNA preparations was determined relative to the extent of hybridization between homologous tracer and driver (unlabelled DNA) DNA preparations.

\section{RESULTS}

The hybridization data (Table 2) show that the endosymbionts tested are genetically diverse and can be separated into at least four distinct groups.

$M u, n u$ and pi particles. $\mathrm{Mu}, \mathrm{nu}$ or pi driver DNA preparations were at least $40 \%$ homologous with tracer DNA from $540 \mathrm{mu}$ or $1010 \mathrm{nu}$ showing that mu, nu and pi are closely 
Table 1. Strains used

\begin{tabular}{|c|c|c|c|c|c|}
\hline \multicolumn{3}{|c|}{ Symbiont } & \multirow{2}{*}{\multicolumn{2}{|c|}{$\begin{array}{l}\text { Pre-lethal } \\
\text { effect or } \\
\text { killing } \\
\text { activity }\end{array}$}} & \multirow[b]{2}{*}{ Origin of species } \\
\hline Binomial name & Greek letter & Stock & & & \\
\hline $\begin{array}{l}\text { Caedobacter } \\
\text { taeniospiralis }\end{array}$ & Kappa (class 51) & 47 & $\begin{array}{l}\text { Paramecium } \\
\text { tetraurelia }\end{array}$ & Huḿp-killer & Berkeley, Calif., U.S.A. \\
\hline C. taeniospiralis & Kappa (class 51) & 51 & P. tetraurelia & Hump-killer & Spencer, Ind., U.S.A. \\
\hline C. taeniospiralis & Kappa (class 51) & 169 & $P$. tetraurelia & Hump-killer & Morioko City, Japan \\
\hline C. taeniospiralis & Kappa (class 51) & A30 & P. tetraurelia & Hump-killer & Australia \\
\hline C. taeniospiralis & Kappa (class 7) & 7 & $P$. biaurelia & Spin-killer & $\begin{array}{l}\text { Pinehurst, N. Carolina, } \\
\text { U.S.A. }\end{array}$ \\
\hline C. taeniospiralis & Kappa (class 7) & 576 & P. biaurelia & Spin-killer & Norwich, England \\
\hline C. taeniospiralis & Kappa (class 7) & 310 & P. biaurelia & $\begin{array}{l}\text { Vacuolizer } \\
\text { Paralyzer }\end{array}$ & New Zealand \\
\hline C. taeniospiralis & Kappa (class 562) & 511 & P. biaurelia & Vacuolizer & Figate, Scotland \\
\hline C. taeniospiralis & Kappa (class 562) & 562 & $P$. biaurelia & Vacuolizer & Milan, Italy \\
\hline C. taeniospiralis & Kappa (class 1038) & 1038 & $P$. biaurèlia & Spin-killer & Syktykar, U.S.S.R. \\
\hline C. taeniospiralis & Kappa (class $51 \mathrm{~m} 1$ ) & $51 \mathrm{~m} 1$ & P. tetraurelia & Spin-killer & Stock 51 \\
\hline C. taeniospiralis & $\mathrm{Pi}$ & 139 & P. tetraurelia & None & Florida, U.S.A. \\
\hline C. conjugatus & Mu & 138 & P. octaurelia & Mate-killer & Florida, U.S.A. \\
\hline C. conjugatus & $\mathrm{Mu}$ & 540 & P. primaurelia & Mate-killer & Mexico \\
\hline C. conjugatus & $\mathrm{Mu}$ & 551 & $P$. primaurelia & Mate-killer & $\begin{array}{l}\text { San Francisco, Calif., } \\
\text { U.S.A. }\end{array}$ \\
\hline C. falsus & $\mathrm{Nu}$ & 1010 & P. biaurelia & None & Tennessee, U.S.A. \\
\hline
\end{tabular}

Table 2. Percentage hybridization of ${ }^{3} H$-labelled tracer DNA with unlabelled driver DNA

\begin{tabular}{|c|c|c|c|c|c|c|}
\hline \multirow{2}{*}{$\begin{array}{c}\text { Source of } \\
\text { driver DNA }\end{array}$} & \multicolumn{6}{|c|}{ Source of ${ }^{3} \mathrm{H}$-labelled tracer DNA } \\
\hline & 51 kappa & 7 kappa & 576 kappa & $1010 \mathrm{nu}$ & $540 \mathrm{mu}$ & 562 kappaphage \\
\hline 47 kappa & 60 & & & & & 14 \\
\hline 51 kappa & 100 & & 4 & 1 & 6 & \\
\hline 169 kappa & 86 & & & & & 7 \\
\hline A30 kappa & 41 & & & & & 5 \\
\hline 7 kappa & $<1$ & 100 & 97 & 1 & 5 & \\
\hline 310 kappa & $<1$ & 75 & 102 & & & \\
\hline 576 kappa & $<1$ & 74 & 100 & 4 & 11 & \\
\hline 511 kappa & 15 & 38 & 41 & & & 76 \\
\hline 1038 kappa & 1 & 43 & 45 & & & \\
\hline 51m1 kappa & $<1$ & 2 & 6 & & & 73 \\
\hline $139 \mathrm{pi}$ & & 3 & 6 & 84 & 73 & \\
\hline $1010 \mathrm{nu}$ & 2 & & & 100 & 40 & \\
\hline $138 \mathrm{mu}$ & & & & 42 & 74 & \\
\hline $540 \mathrm{mu}$ & 1 & & 10 & 47 & 100 & \\
\hline $551 \mathrm{mu}$ & & & & 61 & 70 & \\
\hline 562 kappaphage & & & & & & 100 \\
\hline 51 kappa plasmid & & & & & & 13 \\
\hline E. coli $\mathrm{B}$ & $<1$ & 1 & 2 & 1 & 5 & $<1$ \\
\hline
\end{tabular}

related. Preparations of DNA from strains of mu, nu and pi were less than $12 \%$ homologous with any of the kappa DNA preparations tested.

Class 51 kappa particles. Driver DNA prepared from class 51 hump-killer kappas reassociated significantly only with tracer DNA from 51 kappa. Tracer DNA from 51 kappa did not reassociate with driver DNA prepared from non hump-killer strains of endosymbionts. Clearly hump-killer kappas are a genetically discrete group. They have no close affinities with other types of kappas, except that all are obligate endosymbionts of closely related species of Paramecium and can produce $\mathrm{R}$ bodies.

Kappa particles that infect $P$. biaurelia. Spin-killer (class 7) tracer DNA preparations from 576 kappa and 7 kappa were less than 10\% homologous with driver DNA prepara- 
Table 3. Characteristics of Caedobacter and Pseudocaedobacter

\begin{tabular}{|c|c|c|c|c|c|}
\hline Species name & Type strain & $\begin{array}{c}\text { Host } \\
\text { organism }\end{array}$ & R body & $\begin{array}{l}\text { Killing } \\
\text { activity }\end{array}$ & $\begin{array}{c}\text { Old } \\
\text { species name }\end{array}$ \\
\hline Caedobacter taeniospiralis & 51 kappa & P. tetraurelia & + & Hump-killer & C. taeniospiralis \\
\hline Caedobacter varicaedens & 7 kappa & P. biaurelia & + & $\begin{array}{l}\text { Spin-killer } \\
\text { Paralyzer } \\
\text { Vacuolizer }\end{array}$ & C. taeniospiralis \\
\hline Caedobacter pseudomutans & $51 \mathrm{~m} 1$ kappa & $P$. tetraurelia & + & Spin-killer & C. taeniospiralis \\
\hline Caedobacter paraconjugatus & $570 \mathrm{mu}$ & $P$. biaurelia & + & Mate-killer & C. conjugatus \\
\hline Pseudocaedobacter conjugatus & $540 \mathrm{mu}$ & $\begin{array}{l}P . \text { primaurelia } \\
P . \text { octaurelia }\end{array}$ & - & Mate-killer & C. conjugatus \\
\hline Pseudocaedobacter falsus & $1010 \mathrm{nu}$ & $\begin{array}{l}\text { P. biaurelia } \\
P . \text { tetraurelia } \\
P . \text { pentaurelia }\end{array}$ & - & None & $\begin{array}{l}\text { C. falsus } \\
\text { C. taeniospiralis }\end{array}$ \\
\hline Pseudocaedobacter minutus & 214 gamma & P. octaurelia & - & Vacuolizer & C.minutus \\
\hline
\end{tabular}

tions from 51 kappa, mu or pi endosymbionts. Kappas 576, 7 and 310 are apparently very closely related with a minimum homology of $74 \%$ between them. Driver DNA preparations from 1038 kappa and 511 kappa were 38 to $45 \%$ homologous with spin-killer (class 7) tracer DNA indicating that these organisms also share close genetic ties with class 7 kappa particles.

Class $51 \mathrm{~m} 1$ kappa. Driver DNA from $51 \mathrm{~m} 1$ kappa was not more than $6 \%$ homologous with any of the whole-cell tracer DNA preparations; this strongly suggests that $51 \mathrm{~m} 1$ kappa is not closely related to any of the other endosymbionts tested.

Extrachromosomal DNA from endosymbionts. Covalently closed, circular plasmid DNA was detected only in class 51 hump-killer kappas and in 139 pi. However, the plasmid from 139 pi was only about one-tenth the size of the plasmids from hump-killer kappa particles which ranged from $24 \times 10^{6}$ to $31 \times 10^{6}$ daltons (Quackenbush, 1977b).

Tracer DNA from kappaphage 562 (bacteriophage particles that occur in $562 \mathrm{kappa}$ ) showed only $13 \%$ homology with plasmid DNA from 51 kappa. When hybridized with whole-cell DNA preparations from other class 51 hump-killer kappas, 562 kappaphage tracer DNA showed less than $15 \%$ homology suggesting that there is only a distant relationship between these extrachromosomal elements.

\section{DISCUSSION}

The results presented here support the suggestion (Quackenbush, 1977a) that the genus Caedobacter should be revised. Brenner (1973) has suggested that the amount of deoxyribonucleotide sequence homology between strains of a given bacterial species should be at least $70 \%$. Using this as a general guideline, the genus Caedobacter can be revised. However, the taxa in a good classification should be identifiable by practical laboratory procedures. With this in mind, it is proposed that Caedobacter be split into two genera on the basis of $\mathbf{R}$ body production, a trait that is easily observed by light microscopy. Organisms which can produce $\mathrm{R}$ bodies (commonly known as kappa particles) remain in the genus Caedobacter; those which cannot are placed in a new genus, Pseudocaedobacter (Table 3 ). The $\mathrm{G}+\mathrm{C}$ content of the DNA of Pseudocaedobacter (35 to $39 \mathrm{~mol} \%$ ) is generally lower than that of Caedobacter (40 to $44 \mathrm{~mol} \%$ ).

The genus Caedobacter contains four species distinguished either by the types of killing activity they induce in sensitive strains of paramecia, or by the species of the $P$. aurelia complex that they infect (Table 1). The type species is $C$. taeniospiralis. Since 51 kappa is the type strain of C. taeniospiralis (J. R. Preer et al., 1974), the class 51 hump-killer kappas retain this species designation.

Hybridization data reveal moderately close genetic relationships between class 7 , class 
562 and class 1038 kappas which are assigned to the new species $C$. varicaedens. Members of $C$. varicaedens can be identified by their killing activity and host $(P$. biaurelia). The type strain is 7 kappa.

Although $51 \mathrm{~m} 1$ kappa cannot be distinguished from members of $C$. varicaedens, either morphologically or by killing activity, the hybridization data indicate that it should not be included in $C$. varicaedens. Therefore $51 \mathrm{ml}$ kappa is placed in a new species, C.pseudomutans, which is characterized as a spin-killer that infects $P$. tetraurelia.

The only mate-killer known to produce $\mathrm{R}$ bodies, $570 \mathrm{mu}$, is the fourth species, C. paraconjugatus. Attempts to grow paramecia infected by $570 \mathrm{mu}$ failed, so its genetic affinities with other strains of mu or kappa could not be determined.

The genus Pseudocaedobacter is divided into three species according to killing activity. The type species is Psc. conjugatus comb.nov. It includes all strains of mate-killer endosymbionts except $570 \mathrm{mu}$, which is assigned to $C$. paraconjugatus because it can produce $\mathrm{R}$ bodies. The type strain of Psc. conjugatus is $540 \mathrm{mu}$.

Hybridization data show that pi and nu, which do not have any demonstrable killing activity, are closely related. Therefore they are placed in the same species, Psc. falsus comb.nov. The type strain of Psc. falsus is $1010 \mathrm{nu}$. In the original description of Caedobacter falsus (J. R. Preer et al., 1974) the type strain was incorrectly given as 225 nu which does not exist.

Because they cannot produce $\mathrm{R}$ bodies, gamma are assigned to the species Psc. minutus comb.nov. This species can be distinguished from other species of Pseudocaedobacter by its strong killing activity which is believed not to require cell contact between killer and sensitive paramecia. Although Psc. minutus is found only in low concentrations in host paramecia, it produces strong vacuolization in a broad range of sensitive paramecia from almost all species of the $P$. aurelia complex. The type strain of $P s c$. minutus is 214 gamma (Table 3).

The hybridization data presented here and the assignment of species to Caedobacter closely parallel the classification of kappa by Preer et al. (1972), which was based primarily on $\mathrm{R}$ body morphology, morphology of bacteriophage-like structures present within the kappa particles, and killing activity. Available evidence indicates that these characteristics are at least partially determined by extrachromosomal elements (Preer et al., 1971; L. B. Preer et al., 1974; Dilts, 1976, 1977). The apparent genetic diversity of Caedobacter (kappa) species and the probability that their major phenotypic traits are controlled by extrachromosomal elements could mean that Caedobacter consists of genetically diverse bacteria that carry genetically related extrachromosomal elements. This hypothesis is supported by the fact that tracer DNA from the bacteriophage-like particles occurring in 562 kappa (562 kappaphage) is $73 \%$ homologous with DNA from $51 \mathrm{~m} 1$ kappa (C. pseudomutans) which in turn is less than $15 \%$ homologous with any of the whole-cell tracer DNA used in this investigation. However, less than $14 \%$ of the kappaphage genome is homologous with plasmid DNA from class 51 hump-killer kappas ( $C$. taeniospiralis). All hump-killer kappas carry extrachromosomal DNA in the form of covalently closed, circular plasmids with molecular weights ranging from $25 \times 10^{6}$ to $32 \times 10^{6}$ (Dilts, 1976, 1977; Quackenbush, 1977b) whereas the 562 kappaphage genome has a complexity (amount of non-repeated DNA) of about $40 \times 10^{6}$ (Quackenbush, 1977b). The extrachromosomal elements of kappa that carry genes essential for $\mathbf{R}$ body production thus vary in their physical structure, size and DNA sequence. The extrachromosomal elements of Caedobacter species may be as diverse genetically as are the species themselves. Possibly these extrachromosomal elements had separate origins but it is more likely that at least those portions coding for $\mathbf{R}$ body and toxin production had a common origin and have since diverged. These extrachromosomal elements could have evolved from one form (plasmid or bacteriophage) to another, or the genes for killing activity could have been transferred from their parent molecule (plasmid or bacteriophage DNA) to another species of DNA. A common origin for these genes is 
suggested by the fact that $\mathrm{R}$ bodies and bacteriophage particles from C. varicaedens 562 (562 kappa), C. varicaedens 7 (7 kappa) and C. taeniospiralis 51 (51 kappa) are all immunologically cross-reactive (Singler-Bastiaans, 1975).

\section{Description of new and revised taxonomic groups within the Caedobacteriaceae Preer et al. 1974}

Caedobacter Preer et al. 1974. Gram-negative, non-motile rods or coccobacilli 0.4 to $1.0 \mu \mathrm{m}$ wide and 1.0 to $4.0 \mu \mathrm{m}$ long. Up to $50 \%$ (usually less than $10 \%$ ) of the cells in any given population contain single (rarely double) refractile inclusion bodies ( $R$ bodies). The $\mathrm{R}$ body is a proteinaceous ribbon, approximately $10 \mu \mathrm{m}$ long, $0.5 \mu \mathrm{m}$ wide and $13 \mathrm{~nm}$ thick, which is tightly rolled up within the cell (Anderson et al., 1964). Cells containing $R$ bodies are toxic to certain strains of paramecia and are usually larger than cells that do not contain $\mathrm{R}$ bodies. All species are obligate cytoplasmic endosymbionts of Paramecium biaurelia or $P$. tetraurelia. Culture outside the host organism has not been achieved. The $\mathrm{G}+\mathrm{C}$ content of the DNA ranges from 40 to $44 \mathrm{~mol} \%$. The type species is $C$. taeniospiralis Preer et al. 1974. These organisms are commonly known as kappa particles.

Caedobacter taeniospiralis Preer et al. 1974. Short, Gram-negative, non-motile rods or coccobacilli 0.4 to $0.7 \mu \mathrm{m}$ wide and 1.0 to $2.5 \mu \mathrm{m}$ long. Ingestion of $\mathrm{R}$ body-containing cells by sensitive paramecia usually results in the development of an aboral blister (hump) preceding the death of the paramecium. Obligate cytoplasmic endosymbionts of $P$. tetraurelia. The G + C content of the DNA is $41 \mathrm{~mol} \%$. The type strain is C. taeniospiralis 51 (found in $P$. tetraurelia stock 51).

Caedobacter varicaedens sp.nov. (L. adj. varis different; L. n. caedes act of killing; L. $n$. varicaedens different acts of killing). Gram-negative, non-motile, cigar-shaped rods 0.4 to $1.0 \mu \mathrm{m}$ wide and 1.0 to $4.0 \mu \mathrm{m}$ long. Different strains cause one of three pre-lethal effects in sensitive paramecia after ingestion. These are vacuolization, paralysis or reversal of spinning motion while swimming (spin-killing). Obligate cytoplasmic endosymbionts of $P$. biaurelia. The $\mathrm{G}+\mathrm{C}$ content of the DNA is 40 to $41 \mathrm{~mol} \%$. The type strain is C. varicaedens 7 (found in $P$. biaurelia stock 7 ).

Caedobacter pseudomutans sp.nov. (Gr. adj. pseudo false; L. part. adj. mutans changing; M.L. n. pseudomutans false mutant). Gram-negative, non-motile, cigar-shaped rods approximately $0.5 \mu \mathrm{m}$ wide and $1.5 \mu \mathrm{m}$ long. Most notable pre-lethal effect on sensitive paramecia after ingestion is reversal of spinning motion while swimming. Obligate cytoplasmic endosymbionts of $P$. tetraurelia. The $\mathrm{G}+\mathrm{C}$ content of the DNA is $44 \mathrm{~mol} \%$. The type and only strain is C. pseudomutans $51 \mathrm{~m} 1$ (found in P. tetraurelia stock $51 \mathrm{ml}$ ). Previously believed to be a mutant of $C$. taeniospiralis 51 .

Caedobacter paraconjugatus sp.nov. (Gr. prep. para alike; L. part. conjugatus conjugated; M.L. n. paraconjugatus similar to mate-killers). Small Gram-negative, non-motile rods. Less than $1 \%$ of the cells contain $\mathrm{R}$ bodies, which are smaller than those found in the other species of Caedobacter. Ingestion of cells by sensitive strains of paramecia does not produce any observable toxic effects. Cell-to-cell contact between host and sensitive paramecia is required for toxic effects (mate-killing) to be observed in the sensitive paramecia. Obligate cytoplasmic endosymbionts of $P$. biaurelia. The type and only known strain is $C$. paraconjugatus 570 (found in $P$. biaurelia stock 570 ).

Pseudocaedobacter gen.nov. (Gr. adj. pseudo false; L. n. caedes act of killing; Gr. n. bactrum rod; M.L. n. Pseudocaedobacter false kappa particles). Gram-negative, nonmotile rods 0.25 to $0.7 \mu \mathrm{m}$ wide and 0.5 to $4.0 \mu \mathrm{m}$ long. May or may not confer a killer trait upon their host paramecia. Do not produce $\mathrm{R}$ body-containing cells. Obligate cytoplasmic endosymbionts of $P$. primaurelia, $P$. biaurelia, $P$. tetraurelia, $P$. pentaurelia and $P$. octaurelia. The $\mathrm{G}+\mathrm{C}$ content of the DNA ranges from 35 to $39 \mathrm{~mol} \%$. The type species is Psc. conjugatus originally described by Preer et al. (1974) as Caedobacter conjugatus. 
Pseudocaedobacter conjugatus comb.nov. Previously Caedobacter conjugatus Preer et al. 1974.

Pseudocaedobacter minutus comb.nov. Previously Caedobacter minutus Preer et al. 1974.

Pseudocaedobacter falsus comb.nov. Previously Caedobacter falsus Preer et al. 1974. Obligate cytoplasmic endosymbionts of $P$. biaurelia, $P$. tetraurelia, and $P$. pentaurelia. The type strain is Psc. falsus 1010 (found in P. biaurelia stock 1010). Previously reported type strain (225) does not exist. Commonly known as nu and pi particles. Psc. falsus 51 and Psc. falsus 139 were previously believed to be mutants of $C$. taeniospiralis.

The author wishes to thank John R. Preer, Thomas Blumenthal and H. Michael Shepard for helpful discussions and Bertina Rudman for technical assistance. This investigation was supported by U.S. Public Health Service grant GM20038 from the National Institute of General Medicine to John R. Preer and by U.S. Public Health Service Genetics Training Grant no. 82.

\section{REFERENCES}

Anderson, T. F., Preer, J. R., Preer, L. B. \& BRAY, M. (1964). Studies on killing particles from Paramecium: the structure of refractile bodies from kappa particles. Journal de Microscopie 3, 395-402.

BrenNeR, D. J. (1973). Deoxyribonucleic acid reassociation in the taxonomy of enteric bacteria. International Journal of Systematic Bacteriology 21, 298-307.

Dilts, J. A. (1976). Covalently closed, circular DNA in kappa endosymbionts of Paramecium. Genetical Research 27, 161-170.

Dilts, J. A. (1977). Chromosomal and extrachromosomal deoxyribonucleic acid from four bacterial endosymbionts derived from stock 51 of Paramecium tetraurelia. Journal of Bacterio$\log y$ 129, 888-894.

MuEller, J. A. (1963). Separation of kappa particles with infective activity from those with killing activity and identification of the infective particles in Paramecium aurelia. Experimental Cell Research 30, 492-508.

Preer, J. R., JR \& Preer, L. B. (1967). Virus-like bodies in killer paramecia. Proceedings of the National Academy of Sciences of the United States of America 58, 1774-1781.

Preer, J. R., JR, Preer, L. B., Rudman, B. M. \& JURAND, A. (1971). Isolation and composition of bacteriophage-like particles from kappa of killer paramecia. Molecular and General Genetics 111, 202-208.

Preer, J. R., JR, Preer, L. B. \& Jurand, A. (1974). Kappa and other endosymbionts in Paramecium aurelia. Bacteriological Reviews 38, 113-163.

Preer, L. B., Jurand, A., Preer, J. R., JR \&
Rudman, B. M. (1972). The classes of kappa in Paramecium aurelia. Journal of Cell Science 11, 581-600.

Preer, L. B., Rudman, B. M., Preer, J. R., JR \& JURAND, A. (1974). Induction of $R$ bodies by ultraviolet light in killer paramecia. Journal of General Microbiology 80, 209-215.

QuACKenBush, R. L. (1977a). Phylogenetic relationships of bacterial endosymbionts of Paramecium aurelia: polynucleotide sequence relationships of 51 kappa and its mutants. Journal of Bacteriology 129, 895-900.

QUACKenBuSh, R. L. (1977b). Genetic relationships among bacterial endosymbionts of Paramecium aurelia. Ph.D. thesis, Indiana University, Bloomington, Indiana, U.S.A.

Singler-BASTIAANS, M. J. (1975). Studies with killer paramecia. Ph.D. thesis, Indiana University, Bloomington, Indiana, U.S.A.

SMITH, J. E. (1961). Purification of kappa particles of Paramecium aurelia, stock 51. American Zoologist 1, 390.

Soldo, A. T., Godoy, G. A. \& Van Wagtendonk, W. J. (1966). Growth of particle-bearing and particle-free Paramecium aurelia in axenic culture. Journal of Protozoology 13, 492-497.

Sonneborn, T. M. (1970). Methods in Cell Physiology 4, 242-339.

SONNEBORN, T. M. (1975). The Paramecium aurelia complex of fourteen sibling species. Transactions of the American Microscopical Society 94, 155-178.

Thompson, R., Hughes, S. G. \& BrodA, P. (1974). Plasmid identification using specific endonucleases. Molecular and General Genetics 133. 141-149. 